\title{
Position paper on the safety/efficacy profile of Direct Oral Anticoagulants in patients with Chronic Kidney Disease: Consensus document of Società Italiana di Nefrologia (SIN), Federazione Centri per la diagnosi della trombosi e la Sorveglianza delle terapie Antitrombotiche (FCSA) and Società Italiana per lo Studio dell'Emostasi e della Trombosi (SISET)
}

\author{
Elvira Grandone ${ }^{1,2}\left(\right.$ Filippo Aucella ${ }^{3} \cdot$ Doris Barcellona ${ }^{4,14} \cdot$ Giuliano Brunori $^{5} \cdot$ Giacomo Forneris $^{6} \cdot$ Paolo Gresele $^{7}$. \\ Marco Marietta ${ }^{8}$. Daniela Poli ${ }^{9}$. Sophie Testa ${ }^{10}$. Armando Tripodi $^{11}$. Simonetta Genovesi ${ }^{12,13}$ (1)
}

Received: 6 April 2020 / Accepted: 29 May 2020 / Published online: 31 July 2020

(C) The Author(s) 2020

\begin{abstract}
Direct oral anticoagulants (DOAC) are mostly prescribed to prevent cardioembolic stroke in patients with non-valvular atrial fibrillation (AF). An increasing number of guidelines recommend DOAC in AF patients with preserved renal function for the prevention of thromboembolism and an increased use of DOAC in daily practice is recorded also in elderly patients. Aging is associated with a reduction of glomerular filtration rate and impaired renal function, regardless of the cause, increases the risk of bleeding. Multiple medication use (polypharmacy) for treating superimposed co-morbidities is common in both elderly and chronic kidney disease (CKD) patients and drug-drug interaction may cause accumulation of DOAC, thereby increasing the risk of bleeding. There is uncertainty on the safety profile of DOAC in patients with CKD, particularly in those with severely impaired renal function or end stage renal disease, due to the heterogeneity of studies and the relative paucity of data. This document reports the position of three Italian scientific societies engaged in the management of patients with atrial fibrillation who are treated with DOAC and present with CKD.
\end{abstract}

Keywords Direct oral anticoagulants · Glomerular filtration rate $\cdot$ Chronic kidney disease $\cdot$ Elderly $\cdot$ Polypharmacy

Simonetta Genovesi

simonetta.genovesi@unimib.it

1 Thrombosis and Haemostasis Unit, Fondazione IRCCS "Casa Sollievo della Sofferenza", San Giovanni Rotondo, Italy

2 Ob/Gyn Department of the First I.M. Sechenov, Moscow State Medical University, Moscow, Russia

3 Nephrology and Dialysis Unit, Fondazione IRCCS "Casa Sollievo della Sofferenza”, San Giovanni Rotondo, Italy

4 Department of Medical Sciences and Public Health, University of Cagliari, Cagliari, Italy

5 Nephrology and Dialysis Unit, S. Chiara Hospital, Trento, Italy

6 Department of Clinical and Biological Sciences, University of Turin, Turin, Italy

7 Department of Medicine, Section of Internal and Cardiovascular Medicine, University of Perugia, Perugia, Italy
8 Department of Medical and Surgical Sciences, Section of Hematology, University of Modena and Reggio Emilia, Modena, Italy

9 Center for Atherothrombotic Diseases, Azienda Ospedaliero-Universitaria Careggi, Firenze, Italy

10 Haemostasis and Thrombosis Center, ASST Cremona, Cremona, Italy

11 Angelo Bianchi Bonomi Hemophilia and Thrombosis Center and Fondazione Luigi Villa, Fondazione IRCCS Ca' Granda Ospedale Maggiore Policlinico, Milano, Italy

12 University of Milan-Bicocca, Milano, Italy

13 Nephrology Unit, San Gerardo Hospital, Monza, Italy

14 SHRO Temple University, Philadelphia, USA 


\section{Introduction}

Vitamin K antagonists (VKA) and direct oral anticoagulants (DOAC) are widely prescribed for non-valvular atrial fibrillation (AF) and treatment/prophylaxis of venous thromboembolism. There is a large body of literature in favor of DOAC for the prevention of cardioembolic stroke in patients with preserved renal function and an increasing number of guidelines now recommend DOAC for this and other clinical indications [1]. This has led to an increased use of DOAC in daily practice also in elderly and frail patients.

Polypharmacy is frequent in elderly individuals because of the presence of several co-morbidities and many important interactions between several drugs and VKA or DOAC have been reported. The interaction between VKA and drugs that modify cytochrome $2 \mathrm{C} 9$ and/or $3 \mathrm{~A} 4$ is well known, as well as the interaction between DOAC and drugs that modify p-glycoprotein or cytochrome $3 \mathrm{~A} 4$ [2].

Glomerular filtration rate (GFR) decreases progressively with age, thus increasing the risk of bleeding. DOAC undergo renal elimination to a variable extent (dabigatran about $80 \%$, rivaroxaban $36 \%$, apixaban $27 \%$ and edoxaban 50\%) and can therefore accumulate in patients with declining renal function. Hence, dose adjustment is recommended [3]. Indeed, in young and healthy patients the pharmacokinetic profile of these medications is more predictable than in elderly multimorbid and polypharmacy patients. Except for dabigatran, which is removed by $50-60 \%$ with a single dialysis session, other DOAC are difficult to dialyze due to their high binding to plasma proteins [4].

When bleeding complications occur or in case of urgent/ emergency surgery, the effect of dabigatran can be reversed using idarucizumab, whereas the activity of FXa inhibitors can be reversed by andexanet alfa, that is already on the market in the US and will be soon available in Europe. However, there is limited experience with these antidotes in clinical practice, as the number of patients so far treated is rather limited [5].

Very recently, hemoperfusion by means of an approved adsorption device has been shown to be able to remove rivaroxaban and dabigatran in vivo $[6,7]$. These preliminary reports create the conditions for a possible all-inclusive method for elimination of dabigatran and FXa antagonists using a Cytosorb absorption column.

There is uncertainty on the safety profile of DOAC in patients with chronic kidney disease (CKD), particularly in those with severely impaired renal function or end stage renal disease (ESRD) [8]. On the other hand, in CKD patients AF is associated with an increased rate of ESRD [9, $10]$ and it has been described that oral anticoagulant treatment in these patients is associated with an increased risk of bleeding events [11]. Table 1 summarizes the present position of different scientific societies with regard to the use of DOAC in patients with CKD.

In this position paper the CKD stages are defined according to the KDIGO 2012 Clinical Practice Guideline for the Evaluation and Management of Chronic Kidney Disease [12].

Table 1 Recommendations by scientific societies

\begin{tabular}{|c|c|c|c|}
\hline Guideline & $\begin{array}{l}\text { eGFR } 30-50 \mathrm{ml} / \mathrm{min} \text { (Cockroft- } \\
\text { Gault formula) }\end{array}$ & $\begin{array}{l}\text { eGFR } 15-30 \mathrm{ml} / \mathrm{min} \text { (Cockroft- } \\
\text { Gault formula) }\end{array}$ & $\begin{array}{l}\text { eGFR }<15 \mathrm{ml} / \mathrm{min} \text { (Cockroft-Gault } \\
\text { formula) or ESRD }\end{array}$ \\
\hline ESC, Steffel (2018) [63]* & $\begin{array}{l}110 \mathrm{mg} \text { bid Dabigatran } \\
15 \mathrm{mg} / \text { die Rivaroxaban } \\
2.5 \mathrm{mg} \text { bid Apixaban if } \\
\text { weight }<60 \mathrm{~kg} \text { or age }>80 \mathrm{yrs} \text {; } \\
30 \mathrm{mg} / \text { die Edoxaban }\end{array}$ & $\begin{array}{l}15 \mathrm{mg} / \text { die Rivaroxaban } \\
2.5 \mathrm{mg} \text { bid Apixaban if } \\
\text { weight }<60 \mathrm{~kg} \text { or age }>80 \mathrm{yrs} \text {; } \\
30 \mathrm{mg} / \text { die Edoxaban }\end{array}$ & Avoid DOAC \\
\hline AHA, January (2019) [64]* & $\begin{array}{l}150-110 \mathrm{mg} \text { bid Dabigatran } \\
15 \mathrm{mg} / \text { die Rivaroxaban } \\
2.5 \mathrm{mg} \text { bid Apixaban if cre- } \\
\text { atinine }>1.5 \mathrm{mg} / \mathrm{dl} \text { and } \\
\text { weight }<60 \mathrm{~kg} \text { or age }>80 \mathrm{yrs} \text {; } \\
30 \mathrm{mg} / \text { die Edoxaban }\end{array}$ & $\begin{array}{l}75 \mathrm{mg} \text { bid Dabigatran } \\
15 \mathrm{mg} / \text { die Rivaroxaban } \\
2.5 \mathrm{mg} \text { bid Apixaban if cre- } \\
\text { atinine } \geq 1.5 \mathrm{mg} / \mathrm{dl} \text { and } \\
\text { weight }<60 \mathrm{~kg} \text { or age }>80 \mathrm{yrs} \text {; } \\
30 \mathrm{mg} / \text { die Edoxaban }\end{array}$ & $\begin{array}{l}2.5 \text { or } 5 \mathrm{mg} \text { bid Apixaban might be } \\
\text { considered }\end{array}$ \\
\hline KDIGO, Turakhia (2018) [53] & $\begin{array}{l}110 \mathrm{mg} \text { bid Dabigatran } \\
15 \mathrm{mg} / \text { die Rivaroxaban } \\
2.5 \mathrm{mg} \text { bid Apixaban } \\
30 \mathrm{mg} / \text { die Edoxaban }\end{array}$ & $\begin{array}{l}15 \mathrm{mg} / \text { die Rivaroxaban } \\
2.5 \mathrm{mg} \text { bid Apixaban if cre- } \\
\text { atinine } \geq 1.5 \mathrm{mg} / \mathrm{dl} \text { and } \\
\text { weight }<60 \mathrm{~kg} \text { or age }>80 \mathrm{yrs} \text {; } \\
30 \mathrm{mg} / \text { die Edoxaban }\end{array}$ & $\begin{array}{l}2.5 \mathrm{mg} \text { bid Apixaban might be } \\
\text { considered }\end{array}$ \\
\hline
\end{tabular}

ESRD end stage renal disease, ESC European Society of Cardiology, AHA American Heart Association, KDIGO kidney disease improving global outcomes

*It is recommended to carefully monitor the renal function at an interval depending on the individual degree of renal dysfunction 
Although the Food and Drug Administration (FDA) approved DOAC use for patients with CKD stage G5 [13], none of the randomized controlled trials (RCT) on DOAC included patients with estimated GFR (eGFR) $<25 \mathrm{ml} / \mathrm{min}$. Moreover, extreme caution is recommended as the FDA indications are mainly based on pharmacokinetic data. FDA allows the prescription of rivaroxaban $(15 \mathrm{mg} /$ day $)$ and apixaban (5 mg twice a day) in patients with ESRD or undergoing dialysis if the body weight is $>60 \mathrm{~kg}$ or age $<80$ years, whereas the European Medicines Agency (EMA) contraindicates the use of any DOAC in patients with CKD stage G4-G5.

This paper aims to report the position of three Italian scientific societies that are engaged in the management of patients on DOAC who present with CKD.

\section{Use of DOAC in CKD: available evidence on safety/efficacy profile in RCTs}

The four most frequently used DOAC (dabigatran, rivaroxaban, apixaban and edoxaban) have been compared to warfarin in several RCTs. In all trials, the presence of CKD stage G4-G5 was considered an exclusion criterion [for dabigatran, rivaroxaban and edoxaban and eGFR $<25 \mathrm{ml} /$ min or serum creatinine $>2.5 \mathrm{mg} / \mathrm{dL}$ for apixaban]. In the presence of eGFR $<50 \mathrm{~mL} / \mathrm{min}$, the doses of DOAC were reduced: from 150 to $110 \mathrm{mg}$ twice daily for dabigatran, from 20 to $15 \mathrm{mg}$ once a day for rivaroxaban, from 60 to $30 \mathrm{mg}$ once daily for edoxaban. The dose of apixaban was reduced to $2.5 \mathrm{mg}$ twice daily in the presence of serum creatinine $>1.5 \mathrm{mg} / \mathrm{dL}$, but only if associated with a body weight $<60 \mathrm{~kg}$ and/or age $>80$ years.

Since renal function was not considered as a randomization criterion in any RCT, data from the CKD patients subgroup recruited should be considered as post-hoc analysis results. All post-hoc analyses have shown that the performance of DOAC, both in terms of safety and efficacy, was maintained also in patients with CKD stage G1 to G3b [14-17]. A similar safety result was obtained from a recent post-hoc analysis including $269 \mathrm{G} 4$ patients from the ARISTOTLE trial, treated with apixaban [18]. A systemic meta-analysis carried out by Zou et al. [19] that included five RCTs involving 72,608 patients, indicated that the risk of stroke was lower for DOAC- than for warfarin-treated patients with CKD stage 1 to $3 \mathrm{~b}$. In the same CKD stages DOAC were also associated with fewer major bleedings. In addition, there was a lower risk of hemorrhagic stroke in patients taking DOAC compared to warfarin [20]. However, among patients treated with DOAC, a lower dosage was associated with a higher risk of stroke or systemic embolism [19]. It is noteworthy that these data cannot be extended to the ESRD population, as the only available
RCT (the RENAL-AF trial) showed a similar rate of major and clinically relevant non-major bleedings with apixaban and warfarin in these patients. However, this study was terminated prematurely and its power was limited by the small sample size. [RENal hemodialysis patients ALlocated apixaban versus warfarin in Atrial Fibrillation-RENAL-AF (NCT02942407). Abstract 20963, American Heart Association Annual Scientific Sessions, Philadelphia, 2019].

A systemic review with meta-regression analysis carried out by Nielsen et al. [21] included five RCTs (warfarin vs. DOAC) on 72,845 patients. The analysis suggests that apixaban and edoxaban are associated with a better safety profile in patients with CKD stages G1 to G3b. Actually, patients taking apixaban had less major bleeding events compared to those taking dabigatran (both doses), rivaroxaban or edoxaban at a dose of $60 \mathrm{mg}$, but not to those taking $30 \mathrm{mg}$ of edoxaban. However, the analysis did neither provide any sufficient information on different dosages of apixaban and rivaroxaban nor supply any conclusions regarding to which DOAC is the best choice in this particular setting.

A Cochrane review reported that DOAC could be more effective than warfarin (moderate certainty evidence) in reducing the incidence of stroke and systemic embolism (five studies, 12,545 patients: RR $0.81,95 \%$ CI $0.65-1.00$ ) and major bleeding events (five studies, 12,521 patients: RR $0.79,95 \%$ CI 0.59-1.04; low certainty evidence). However, these data were obtained mainly in patients $(n=12,155)$ with G3b stage, as the group of G4 stage consisted of only 390 patients [22].

Statement: Data from RCTs show that DOAC have at least similar safety and efficacy profiles in patients with CKD stages G2 to G3b and in patients with normal renal function.

Statement: In patients with CKD G4 DOAC should be used with caution because of lack of strong supporting evidence from RCTs. At present there are not enough data available to recommend the use of DOAC in patients with CKD G5 or on long term dialysis.

\section{Use of DOAC in CKD: available evidence on safety and efficacy profile in real-life studies}

The main available real-life studies performed in CKD patients taking DOAC are summarized in Table 2. Since real-life studies often show mostly aggregated data without distinguishing patients treated with VKA from those treated with DOAC, it is not possible to draw meaningful conclusions regarding the subgroups of patients taking DOAC. Furthermore, these studies are mainly retrospective and therefore of limited value. A paper by Kumar 
Table 2 Description of real-life studies including chronic kidney disease patients

\begin{tabular}{|c|c|c|c|c|c|c|}
\hline Author & Study design & $\begin{array}{l}\text { Patients tak- } \\
\text { ing DOAC } \\
(n)\end{array}$ & DOAC type & $\begin{array}{l}\text { HR }(95 \% \mathrm{CI}) \text { bleed- } \\
\text { ing/stroke (DOAC vs. } \\
\text { reference group) }\end{array}$ & Reference group & Limitations \\
\hline Lee (2015) [29] & $\begin{array}{l}\text { Retrospective G3, } \\
\text { G4 patients }\end{array}$ & 59 & $\begin{array}{l}\text { Rivaroxaban } \\
\text { Dabigatran }\end{array}$ & $\begin{array}{l}0.18(0.07-0.45) / 0.78 \\
\quad(0.21-3.00)\end{array}$ & VKA & Small sample size \\
\hline Chan (2015) [34] & $\begin{array}{l}\text { Retrospective G5 } \\
\text { patients }\end{array}$ & 525 & $\begin{array}{l}\text { Rivaroxaban } \\
\text { Dabigatran }\end{array}$ & $\begin{array}{l}1.38(1.03-1.83) \\
\text { (Rivaroxaban); } 1.48 \\
(1.21-1.81)(\text { Dabi- } \\
\text { gatran)/na }\end{array}$ & VKA & $\begin{array}{l}\text { Data on stroke not } \\
\text { available }\end{array}$ \\
\hline Harel (2016) [25] & $\begin{array}{l}\text { Population-based } \\
\text { nested case- } \\
\text { control G3, G4 } \\
\text { patients }\end{array}$ & 570 & $\begin{array}{l}\text { Rivaroxaban } \\
\text { Dabigatran }\end{array}$ & $\begin{array}{l}1.22(0.83-1.79) \\
\quad \text { Rivaroxaban); } 1.15 \\
(0.91-1.45)(\text { Dabi- } \\
\text { gatran)/na }\end{array}$ & VKA & $\begin{array}{l}\text { Administrative } \\
\text { database } \\
\text { Data on stroke not } \\
\text { available }\end{array}$ \\
\hline $\begin{array}{l}\text { Stanton (2017) } \\
\text { [26] }\end{array}$ & $\begin{array}{l}\text { Retrospective G4 } \\
\text { patients }\end{array}$ & 78 & Apixaban & $\begin{array}{l}\text { No difference in } \\
\text { bleeding and stroke }\end{array}$ & VKA & Small sample size \\
\hline Sarrat (2017) [33] & $\begin{array}{l}\text { Retrospective G5 } \\
\text { patients }\end{array}$ & 40 & Apixaban & $\begin{array}{l}\text { No difference in } \\
\text { bleeding/na }\end{array}$ & VKA & $\begin{array}{l}\text { Small sample size } \\
\text { Data on stroke not } \\
\text { available }\end{array}$ \\
\hline $\begin{array}{l}\text { Becattini (2018) } \\
\text { [32] }\end{array}$ & $\begin{array}{l}\text { Prospective G2, } \\
\text { G3, G4 patients }\end{array}$ & 449 & $\begin{array}{l}\text { Dabigatran } \\
\text { Rivaroxaban } \\
\text { Apixaban }\end{array}$ & $\begin{array}{l}1.02(1.01-1.04) \text { every } \\
1 \mathrm{ml} / \mathrm{min} \text { decrease in } \\
\mathrm{eGFR} / \mathrm{na}\end{array}$ & $\begin{array}{l}\text { Not worsening } \\
\text { renal function }\end{array}$ & $\begin{array}{l}\text { Data on stroke not } \\
\text { available }\end{array}$ \\
\hline Siontis (2018) [35] & $\begin{array}{l}\text { Retrospective G5 } \\
\text { patients }\end{array}$ & 2351 & Apixaban & $\begin{array}{l}0.71(0.56-0.91) / 1.11 \\
(0.82-1.50)(2.5 \mathrm{mg} \\
\text { bid }) \\
0.71(0.53-0.95) / 0.64 \\
(0.42-0.97) \\
(5 \mathrm{mg} \text { bid })\end{array}$ & VKA & $\begin{array}{l}\text { Medicare benefi- } \\
\text { ciaries }\end{array}$ \\
\hline Kumar (2018) [23] & $\begin{array}{l}\text { Population-based } \\
\text { retrospective G3- } \\
\text { G4 patients }\end{array}$ & 641 & $\begin{array}{l}\text { Rivaroxaban } \\
\text { Apixaban Dabi- } \\
\text { gatran } \\
\text { Edoxaban (4 } \\
\text { patients) }\end{array}$ & $\begin{array}{l}2.42(1.44-4.05) / 2.60 \\
\quad(2.00-3.38) \\
(\mathrm{DOAC}+\mathrm{VKA})\end{array}$ & No anticoagulation & $\begin{array}{l}\text { Pooled data with } \\
\text { VKA }\end{array}$ \\
\hline Schafer (2018) [31] & $\begin{array}{l}\text { Retrospective G4- } \\
\text { G5 patients }\end{array}$ & 302 & Apixaban & $\begin{array}{l}\text { No difference in } \\
\text { bleeding and stroke } \\
\text { at } 0 \text { to } 3 \text { months } \\
0.16(0.05-0.50) \\
\text { at } 6-12 \text { months/ } \\
\text { no difference at } \\
6-12 \text { months }\end{array}$ & VKA & $\begin{array}{l}\text { Administrative } \\
\text { Database }\end{array}$ \\
\hline Shin (2018) [28] & $\begin{array}{l}\text { Retrospective, G3- } \\
\text { G4 pts }\end{array}$ & 1168 & $\begin{array}{l}\text { Dabigatran } \\
\text { Rivaroxaban } \\
\text { Apixaban }\end{array}$ & $\begin{array}{l}1.23(1.02-1.48) / 1.02 \\
(0.76-1.37)\end{array}$ & VKA & $\begin{array}{l}\text { Administrative } \\
\text { database }\end{array}$ \\
\hline $\begin{array}{l}\text { Bonnemeier (2019) } \\
\text { [27] }\end{array}$ & $\begin{array}{l}\text { Retrospective, } \\
\text { CKD patients }\end{array}$ & 6102 & Rivaroxaban & $\begin{array}{l}0.66(0.38-1.14) / 0.72 \\
\quad(0.55-0.94)\end{array}$ & VKA & $\begin{array}{l}\text { Administrative } \\
\text { database }\end{array}$ \\
\hline $\begin{array}{l}\text { Coleman (2019) } \\
\text { [30] }\end{array}$ & $\begin{array}{l}\text { Retrospective, G4- } \\
\text { G5 patients }\end{array}$ & 1896 & Rivaroxaban & $\begin{array}{l}-32 \% \\
\quad(1-53 \%) / 0.67(0.30- \\
1.50)\end{array}$ & VKA & $\begin{array}{l}\text { Administrative } \\
\text { database }\end{array}$ \\
\hline $\begin{array}{l}\text { Makani (2020) } \\
\text { [65] }\end{array}$ & $\begin{array}{l}\text { Retrospective, G3- } \\
\text { G4-G5 patients }\end{array}$ & 10,794 & $\begin{array}{l}\text { Dabigatran Rivar- } \\
\text { oxaban Apixaban } \\
\text { Edoxaban (11 } \\
\text { patients) }\end{array}$ & $\begin{array}{l}\text { G3 } 0.83(0.74-0.94) / \\
\text { na } \\
\text { G4-G5 } 0.69(0.50- \\
\text { 0.93)/na }\end{array}$ & VKA & $\begin{array}{l}\text { Compliance to } \\
\text { treatment }\end{array}$ \\
\hline
\end{tabular}

$H R$ hazard ratio, $C I$ confidence interval, $V K A$ vitamin $\mathrm{K}$ antagonist

et al. reports on 641 patients treated with DOAC, but the analysis does not allow to identify features of the CDK subgroup [23]. A retrospective Italian study showed a reduction in bleeding and a better efficacy profile in patients taking rivaroxaban compared to warfarin. However, some caution should be used in generalizing these data, as the events rate described in this study is very different from that of other studies (25 stroke episodes of 
which 15 hemorrhagic in 100 patients taking warfarin vs. none in 247 taking rivaroxaban) [24].

With regard to bleeding, data in G3-G4 CKD patients are not univocal. Indeed, some authors report no difference in the incidence of bleeding events between DOAC and VKA [25-27], some describe a higher number of bleeding events in patients taking DOAC [28], while others report lower incidence in patients taking DOAC [29, 30]. On the other hand, most studies agree that DOAC and VKA are equally effective in the prevention of thromboembolic risk in CKD patients [25, 26, 28-31].

For what regards the use of DOAC in ESRD patients undergoing dialysis, there are no conclusive data.

Recently, a study on 449 patients with a follow-up of about 18 months showed that variations of eGFR over time are inversely and independently related with the risk of bleeding: $1 \mathrm{~mL} / \mathrm{min}$ absolute decrease in eGFR was associated with a $2 \%$ increase in the risk of both major and nonmajor bleeding [32].

Retrospective matched-cohort studies comparing apixaban and warfarin, performed in small numbers of severe CKD and ESRD patients, showed non-significant differences in the occurrence of major bleeding between DOAC and VKA groups, with similar rates of ischemic stroke [26, 31, 33]. In hemodialysis patients, Chan et al. [34] demonstrated a higher risk of death from bleeding with dabigatran and rivaroxaban compared to warfarin, whereas Siontis et al. [35] showed no difference in the rate of thromboembolic events between apixaban and warfarin, with a lower risk of bleeding in patients taking apixaban. Finally, a recent metaanalysis of observational studies carried out in patients on long-term dialysis showed that VKA, dabigatran and rivaroxaban are associated with a significantly higher bleeding risk compared with apixaban and no anticoagulant treatment. However, only two of the sixteen studies included had investigated DOAC and there was significant heterogeneity in the analysis. Consequently, the authors state that to draw conclusions on the benefit-to-risk ratio in patients on longterm dialysis RCTs are warranted [36].

There is some concern about the association between VKA and vascular calcifications [37], observed particularly in the elderly taking warfarin [38], even if some authors find that CKD patients are exposed to calcifications independently of warfarin intake [39, 40]. Indeed, vascular calcifications could expose to an increased risk of cardiovascular events [39-42]. In this respect, it has been suggested that DOAC may have a better performance in CKD patients [43]. One RCT performed in a population of hemodialysis patients with AF (VKA replacement by rivaroxaban with or without high dose of vitamin K) however, showed that withdrawal of VKA and addition of high-dose vitamin K2 improved the vitamin $\mathrm{K}$ status, but did not reduce the progression of vascular calcifications [44].
Warfarin-related nephropathy is a clinical-pathologic entity that is often underdiagnosed, which occurs in the setting of an INR of $>3.0[42,45]$ and leads to acute kidney injury. In addition, in CKD patients, AF is associated with a faster progression towards $\operatorname{ESRD}[9,10]$.

It has been hypothesized that in AF patients the use of DOAC is associated with both a lower risk of acute kidney injury and a slowdown in the deterioration of renal function when compared to VKA. Even if the data that are available so far are promising, they are not conclusive however, due to the retrospective nature of these studies $[10,28,30]$. A recent meta-analysis including 189,483 patients from eleven RCTs and three observational database studies $(119,188$ patients on DOACs and 70,295 patients on VKA or acetylsalicylic acid) suggested a significantly lower risk of renal impairment in AF patients with DOAC versus VKAs/acetylsalicylic acid (HR 0.67, 95\% CI 0.62-0.73). The results did not change when considering a stricter definition of renal impairment (HR 0.65, 95\% CI 0.60-0.71). Final conclusions are not robust however, because the analysis was performed by pooling data deriving both from patients taking acetylsalicylic acid and from those on warfarin treatment [46].

Statement: Data from observational studies suggest that DOAC have at least similar efficacy and safety profiles as VKA in patients with CKD stage G2 to G3b.

Statement: In patients with CKD G4-G5, also on long-term dialysis, DOAC should be used with caution, because of the small sample size of patients investigated and heterogeneity of studies.

Statement: Data on the interaction between DOAC, vascular calcifications and worsening of renal function in CKD patients are still not conclusive.

\section{Dosing DOAC in CKD patients}

Since 2013 the Subcommittee on control of anticoagulation of the scientific and standardization committee of the International Society on Thrombosis and Haemostasis (ISTH) has recommended to measure DOAC plasma levels in some special clinical circumstances including (1) active bleeding; (2) before surgery/invasive procedure when the patient has taken the drug in the previous $24 \mathrm{~h}$, or longer if CKD stage $3 \mathrm{~b}$ or higher; (3) patients with deteriorating renal function; (4) perioperative management; (5) identification of subtherapeutic or supratherapeutic levels in patients at the extremes of body weight [47].

The plasma concentration of DOAC can be measured by relatively simple functional assays for both FIIa (dabigatran) and FXa inhibitors (rivaroxaban, apixaban, edoxaban) [48]. The tests for dabigatran are the dilute 
thrombin time or the ecarin clotting (or chromogenic) assays, whereas anti-FXa drugs can be measured by the anti-FXa assay [49].

Several reports have shown that there is a great variability among patients on DOAC, and that plasma levels poorly correlate with eGFR [50, 51]. Furthermore, recent observations show that bleeding complications are more frequent in patients with higher DOAC plasma levels at peak [52].

Several scientific societies suggest to measure DOAC prior to invasive procedures or surgery independently of eGFR. This is particularly recommended in elderly patients, in whom eGFR can vary rapidly over time $[49,53]$. However, accurate definition of reliable cut off values is still lacking and we are waiting for findings from ad hoc studies [54].

A prospective study carried out in 422 patients on DOAC has shown that interrupting DOAC administration 3 days before a procedure was associated with a minimal pre-procedural anticoagulant effect and that both the presence of CKD stage $3 \mathrm{~b}$ or higher and treatment with antiarrhythmic drugs should require a longer period of DOAC discontinuation [55].

A relevant issue is the choice of the most accurate method to calculate eGFR. The reported RCTs used the CockcroftGault equation, that is considered less accurate than the Modification of Diet in Renal Disease Study (MDRD) and the Chronic Kidney Disease Epidemiology Collaboration (CKD-EPI) equations [56-58]. In general, CKD-EPI and MDRD give the best estimation of GFR [59]. Moreover, from a practical point of view, as MDRD or CKD-EPI do not consider body weight, these equations are more suitable in daily practice in the clinical wards, especially for bedridden patients for whom an estimation of weight is difficult to obtain. However, it has been shown that either equations may overestimate eGFR in elderly patients [60-62].

AF in CKD patients confers a high risk of worsening renal function and progression to ESRD $[9,10]$. On the one hand the decrease in eGFR is associated with a higher risk of major and non-major bleeding [31], on the other hand it is associated with a higher risk of drug overdosing. For these reasons it is recommended to carefully monitor renal function in patients taking DOAC.

Statement: Measuring plasma DOAC concentration is recommended in case of (1) active bleeding/thrombosis; (2) urgent/emergency surgery (3) acute states (inflammation, sepsis, dehydration and acute kidney injury stage 2-3) [12].

Statement: Every hospital should have laboratory tests at their disposal for measuring DOAC plasma levels.

Statement: Careful monitoring of renal function in patients taking DOAC is recommended to avoid the risk of overdosing.

\section{Definitions}

Chronic kidney disease classification according to estimated glomerular filtration rate.

$\mathrm{G} 1:>90 \mathrm{ml} / \mathrm{min}$.

G2: $60-89 \mathrm{ml} / \mathrm{min}$.

G3: $30-59 \mathrm{ml} / \mathrm{min}-\mathrm{G} 3 \mathrm{a}: 45-49 \mathrm{ml} / \mathrm{min}-\mathrm{G} 3 \mathrm{~b}$ : $30-44 \mathrm{ml} / \mathrm{min}$.

G4: $15-29 \mathrm{ml} / \mathrm{min}$.

$\mathrm{G} 5:<15 \mathrm{ml} / \mathrm{min}$.

Funding No financial support was received for the preparation of this manuscript.

\section{Compliance with ethical standards}

Conflict of interest All authors declare that they have no relevant conflicts of interests.

Ethical approval This article does not contain any studies with human participants performed by any of the authors.

Research involving human participants and/or animals For this type of study formal consent is not required.

Informed consent Informed consent was not required since no patients participated in the study.

Open Access This article is licensed under a Creative Commons Attribution 4.0 International License, which permits use, sharing, adaptation, distribution and reproduction in any medium or format, as long as you give appropriate credit to the original author(s) and the source, provide a link to the Creative Commons licence, and indicate if changes were made. The images or other third party material in this article are included in the article's Creative Commons licence, unless indicated otherwise in a credit line to the material. If material is not included in the article's Creative Commons licence and your intended use is not permitted by statutory regulation or exceeds the permitted use, you will need to obtain permission directly from the copyright holder. To view a copy of this licence, visit http://creativecommons.org/licenses/by/4.0/.

\section{References}

1. Makam RCP, Hoaglin DC, Mcmanus DD et al (2018) Efficacy and safety of direct oral anticoagulants approved for cardiovascular indications: systematic review and meta-analysis. PLoS ONE. https://doi.org/10.1371/journal.pone.0197583

2. Vazquez SR (2018) Drug-drug interactions in an era of multiple anticoagulants: a focus on clinically relevant drug interactions. Hematology 132:339-347

3. Shroff GR, Stoecker R, Hart A (2018) Non-vitamin K-dependent oral anticoagulants for nonvalvular atrial fibrillation in patients with CKD: pragmatic considerations for the clinician. Am J Kidney Dis 72:717-727. https://doi.org/10.1053/j. ajkd.2018.02.360

4. Chan KE, Giugliano RP, Patel MR et al (2016) Nonvitamin K anticoagulant agents in patients with advanced chronic kidney 
disease or on dialysis with AF. J Am Coll Cardiol 67:28882899. https://doi.org/10.1016/j.jacc.2016.02.082

5. Grandone E, Ostuni A, Tiscia GL et al (2019) Management of patients taking oral anticoagulants who need urgent surgery for hip fracture. Semin Thromb Hemost 45:164-170. https://doi. org/10.1055/s-0039-1678718

6. Angheloiu AA, Angheloiu GO (2019) Removal of dabigatran using sorbent hemadsorption. Int J Cardiol 293:73-75. https:// doi.org/10.1016/j.ijcard.2019.06.078

7. Koertge A, Wasserkort R, Wild T et al (2018) Letter to the Editor: Extracorporeal hemoperfusion as a potential therapeutic option for critical accumulation of rivaroxaban. Blood Purif 45:126-128. https://doi.org/10.1159/000484923

8. Leung KCW, MacRae JM (2019) Anticoagulation in CKD and ESRD. J Nephrol 32:719-731

9. Bansal N, Fan D, Hsu C et al (2013) Incident atrial fibrillation and risk of end-stage renal disease in adults with chronic kidney disease. Circulation 127:569-574. https://doi.org/10.1161/ CIRCULATIONAHA.112.123992

10. Yao X, Tangri N, Gersh BJ et al (2017) Renal outcomes in anticoagulated patients with atrial fibrillation. J Am Coll Cardiol 70:2621-2632. https://doi.org/10.1016/j.jacc.2017.09.1087

11. Dahal K, Kunwar S, Rijal J et al (2016) Stroke, major bleeding, and mortality outcomes in warfarin users with atrial fibrillation and chronic kidney disease: a meta-analysis of observational studies. Chest 149:951-959. https://doi.org/10.1378/chest .15-1719

12. Eknoyan G et al (2013) KDIGO CPG for evaluation and management of CKD 2013. Kidney Int Suppl. https://doi.org/10.1038/ kisup. 2012.76

13. Food and Drug Administration (2016) Eliquis. Pharmacology. https://doi.org/Reference ID:3237516

14. Hijazi Z, Hohnloser SH, Oldgren J et al (2014) Efficacy and safety of dabigatran compared with warfarin in relation to baseline renal function in patients with atrial fibrillation: a RE-LY (Randomized Evaluation of Long-term Anticoagulation Therapy) trial analysis. Circulation 129:961-970. https://doi.org/10.1161/CIRCULATIO NAHA.113.003628

15. Fox KAA, Piccini JP, Wojdyla D et al (2011) Prevention of stroke and systemic embolism with rivaroxaban compared with warfarin in patients with non-valvular atrial fibrillation and moderate renal impairment. Eur Heart J 32:2387-2394. https://doi.org/10.1093/ eurheartj/ehr342

16. Hijazi Z, Hohnloser SH, Andersson U et al (2016) Efficacy and safety of apixaban compared with warfarin in patients with atrial fibrillation in relation to renal function over time. JAMA Cardiol 1:451. https://doi.org/10.1001/jamacardio.2016.1170

17. Bohula EA, Giugliano RP, Ruff CT et al (2016) Impact of renal function on outcomes with edoxaban in the ENGAGE AF-TIMI 48 trial. Circulation 134:24-36. https://doi.org/10.1161/CIRCU LATIONAHA.116.022361

18. Stanifer JW, Pokorney SD, Chertow GM, et al (2020) Apixaban versus warfarin in patients with atrial fibrillation and advanced chronic kidney disease. Circulation CIRCULATIONAHA.119.044059. https://doi.org/10.1161/ CIRCULATIONAHA.119.044059

19. Zou R, Tao J, Shi W et al (2017) Meta-analysis of safety and efficacy for direct oral anticoagulation treatment of non-valvular atrial fibrillation in relation to renal function. Thromb Res 160:41-50. https://doi.org/10.1016/j.thromres.2017.10.013

20. Raccah BH, Perlman A, Danenberg HD et al (2016) Major bleeding and hemorrhagic stroke with direct oral anticoagulants in patients with renal failure systematic review and metaanalysis of randomized trials. Chest 149:1516-1524. https://doi. org/10.1016/j.chest.2015.12.029
21. Nielsen PB, Deirdre N, Hvilsted L, Gregory R (2015) Renal function and non-vitamin $\mathrm{K}$ oral anticoagulants in comparison with warfarin on safety and efficacy outcomes in atrial fibrillation patients: a systemic review and meta-regression analysis. pp. 418-429. https://doi.org/10.1007/s00392-014-0797-9

22. Kimachi M, Furukawa TA, Kimachi K, et al (2017) Direct oral anticoagulants versus warfarin for preventing stroke and systemic embolic events among atrial fibrillation patients with chronic kidney disease. Cochrane Database Syst Rev 2017(11)

23. Kumar S, De Lusignan S, McGovern A et al (2018) Ischaemic stroke, haemorrhage, and mortality in older patients with chronic kidney disease newly started on anticoagulation for atrial fibrillation: a population based study from UK primary care. BMJ. https ://doi.org/10.1136/bmj.k342

24. Di Lullo TG, Ronco C et al (2018) Safety and effectiveness of rivaroxaban and warfarin in moderate-to-advanced CKD: real world data. J Nephrol 31:751-756. https://doi.org/10.1007/s4062 0-018-0501-7

25. Harel Z, Mamdani M, Juurlink DN et al (2016) Novel oral anticoagulants and the risk of major hemorrhage in elderly patients with chronic kidney disease: a nested case-control study. Can J Cardiol 32:986.e17-986.e22. https://doi.org/10.1016/j.cjca.2016.01.013

26. Stanton BE, Barasch NS, Tellor KB (2017) Comparison of the safety and effectiveness of apixaban versus warfarin in patients with severe renal impairment. Pharmacother J Hum Pharmacol Drug Ther 37:412-419. https://doi.org/10.1002/phar.1905

27. Bonnemeier H, Huelsebeck M, Kloss S (2019) Comparative effectiveness of rivaroxaban versus a vitamin $\mathrm{K}$ antagonist in patients with renal impairment treated for non-valvular atrial fibrillation in Germany-A retrospective cohort study. Int J Cardiol Heart Vasc 23:100367. https://doi.org/10.1016/j.ijcha.2019.100367

28. Shin JI, Secora A, Caleb Alexander G et al (2018) Risks and benefits of direct oral anticoagulants across the spectrum of GFR among incident and prevalent patients with atrial fibrillation. Clin J Am Soc Nephrol 13:1144-1152. https://doi.org/10.2215/ CJN.13811217

29. Lee KJKH, Park HW, Cho JGJY et al (2015) Comparison of nonVitamin $\mathrm{K}$ antagonist oral anticoagulants and warfarin on clinical outcomes in atrial fibrillation patients with renal dysfunction. Europace 17(2):69-75. https://doi.org/10.1093/europace/euv198

30. Coleman CI, Kreutz R, Sood NA et al (2019) Rivaroxaban versus warfarin in patients with nonvalvular atrial fibrillation and severe kidney disease or undergoing hemodialysis. Am J Med 132:1078-1083. https://doi.org/10.1016/j.amjmed.2019.04.013

31. Schafer JH, Casey AL, Dupre KA, Staubes BA (2018) Safety and efficacy of apixaban versus warfarin in patients with advanced chronic kidney disease. Ann Pharmacother 52:1078-1084. https ://doi.org/10.1177/1060028018781853

32. Becattini C, Giustozzi M, Ranalli MG et al (2018) Variation of renal function over time is associated with major bleeding in patients treated with direct oral anticoagulants for atrial fibrillation. J Thromb Haemost 16:833-841. https://doi.org/10.1111/ jth. 13985

33. Sarratt SC, Nesbit R, Moye R (2017) Safety outcomes of apixaban compared with warfarin in patients with end-stage renal disease. Ann Pharmacother 51:445-450. https://doi.org/10.1177/10600 28017694654

34. Chan KE, Edelman ER, Wenger JB et al (2015) Dabigatran and rivaroxaban use in atrial fibrillation patients on hemodialysis. Circulation 131:972-979. https://doi.org/10.1161/CIRCULATIO NAHA.114.014113

35. Siontis KC, Zhang X, Eckard A et al (2018) Outcomes associated with apixaban use in patients with end-stage kidney disease and atrial fibrillation in the United States. Circulation 138:1519-1529. https://doi.org/10.1161/CIRCULATIONAHA.118.035418 
36. Kuno T, Takagi H, Ando T et al (2020) Oral anticoagulation for patients with atrial fibrillation on long-term hemodialysis. J Am Coll Cardiol 75:273-285. https://doi.org/10.1016/j. jacc.2019.10.059

37. Holden RM, Booth SL (2007) Vascular calcification in chronic kidney disease: the role of vitamin K. Nat Clin Pract Nephrol 3:522-523

38. Weijs B, Blaauw Y, Rennenberg RJMW et al (2011) CLINICAL RESEARCH Patients using vitamin $\mathrm{K}$ antagonists show increased levels of coronary calcification: an observational study in low-risk atrial fibrillation patients. Eur Heart J. https://doi.org/10.1093/ eurheartj/ehr241

39. Paloian NJ, Giachelli CM (2014) A current understanding of vascular calcification in CKD. Am J Physiol Ren Physiol 307:F891-F900

40. Krueger T, Westenfeld R, Schurgers L, Brandenburg V (2009) Coagulation meets calcification: the vitamin K system. Int J Artif Organs 32:67-74. https://doi.org/10.1177/039139880903200202

41. Russo D, Corrao S, Battaglia Y et al (2011) Progression of coronary artery calcification and cardiac events in patients with chronic renal disease not receiving dialysis. Kidney Int 80:112118. https://doi.org/10.1038/ki.2011.69

42. Brodsky SV, Nadasdy T, Rovin BH et al (2011) Warfarin-related nephropathy occurs in patients with and without chronic kidney disease and is associated with an increased mortality rate. Kidney Int 80:181-189

43. Plank F, Beyer C, Friedrich $G$ et al (2018) Influence of vitamin $\mathrm{K}$ antagonists and direct oral anticoagulation on coronary artery disease: a CTA analysis. Int J Cardiol 260:11-15. https://doi. org/10.1016/j.ijcard.2018.03.019

44. de Vriese AS, Caluwé R, Pyfferoen L et al (2020) Multicenter randomized controlled trial of Vitamin $\mathrm{K}$ antagonist replacement by rivaroxaban with or without vitamin $\mathrm{K} 2$ in hemodialysis patients with atrial fibrillation: the Valkyrie study. J Am Soc Nephrol 31:186-196. https://doi.org/10.1681/ASN.2019060579

45. Glassock RJ (2019) Anticoagulant-related nephropathy: It's the real McCoy. Clin J Am Soc Nephrol 14:935-937. https://doi. org/10.2215/CJN.02470319

46. Zhang C, Gu ZC, Ding Z et al (2019) Decreased risk of renal impairment in atrial fibrillation patients receiving non-vitamin $\mathrm{K}$ antagonist oral anticoagulants: a pooled analysis of randomized controlled trials and real-world studies. Thromb Res 174:16-23

47. Baglin T, Hillarp A, Tripodi A et al (2013) Measuring oral direct inhibitors of thrombin and factor Xa: A recommendation from the Subcommittee on Control of Anticoagulation of the Scientific and Standardization Committee of the International Society on Thrombosis and Haemostasis. J Thromb Haemost 11:756-760. https://doi.org/10.1111/jth.12149

48. Tripodi A (2013) The laboratory and the direct oral anticoagulants. Blood 121:4032-4035. https://doi.org/10.1182/blood-2012$12-453076$

49. Tripodi A, Marongiu F, Moia M et al (2018) The vexed question of whether or not to measure levels of direct oral anticoagulants before surgery or invasive procedures. Intern Emerg Med 13:1029-1036. https://doi.org/10.1007/s11739-018-1854-6

50. Testa S, Tripodi A, Legnani C et al (2016) Plasma levels of direct oral anticoagulants in real life patients with atrial fibrillation: results observed in four anticoagulation clinics. Thromb Res 137:178-183. https://doi.org/10.1016/j.thromres.2015.12.001

51. Reilly PA, Lehr T, Haertter S et al (2014) The effect of dabigatran plasma concentrations and patient characteristics on the frequency of ischemic stroke and major bleeding in atrial fibrillation patients: the RE-LY trial (Randomized Evaluation of LongTerm Anticoagulation Therapy). J Am Coll Cardiol 63:321-328. https://doi.org/10.1016/j.jacc.2013.07.104

52. Testa S, Legnani C, Antonucci E et al (2019) Drug levels and bleeding complications in atrial fibrillation patients treated with direct oral anticoagulants. J Thromb Haemost 17:1064-1072. https://doi.org/10.1111/jth.14457

53. Turakhia MP, Blankestijn PJ, Carrero J, et al (2018) Chronic kidney disease and arrhythmias : conclusions from a Kidney Disease : Improving Global Outcomes ( KDIGO ) Controversies Conference. 1-17. https://doi.org/10.1093/eurheartj/ehy060

54. Tripodi A, Ageno W, Ciaccio M, et al (2018) Position Paper on laboratory testing for patients on direct oral anticoagulants. A Consensus Document from the SISET, FCSA, SIBioC and SIPMeL. Blood Transfus. 16: 462-470.

55. Godier A, Dincq AS, Line Martin AC et al (2017) Predictors of pre-procedural concentrations of direct oral anticoagulants: a prospective multicentre study. Eur Heart J 38:2431-2439. https://doi. org/10.1093/eurheartj/ehx403

56. Cockcroft DW, Gault MH (1976) Prediction of creatinine clearance from serum creatinine. Nephron 16:31-41. https://doi. org/10.1159/000180580

57. Schaeffner ES, Ebert N, Delanaye P et al (2012) Two novel equations to estimate kidney function in persons aged 70 years or older. Ann Intern Med 157:471-481. https://doi.org/10.7326/0003-4819157-7-201210020-00003

58. Stevens PE, Levin A (2013) Evaluation and management of chronic kidney disease: Synopsis of the kidney disease: improving global outcomes 2012 clinical practice guideline. Ann Intern Med. https://doi.org/10.7326/0003-4819-158-11-201306040-00007

59. Michels WM, Grootendorst DC, Verduijn M et al (2010) Performance of the Cockcroft-Gault, MDRD, and new CKD-EPI formulas in relation to GFR, age, and body size. Clin J Am Soc Nephrol 5:1003-1009. https://doi.org/10.2215/CJN.06870909

60. MacCallum PK, Mathur R, Hull SA et al (2013) Patient safety and estimation of renal function in patients prescribed new oral anticoagulants for stroke prevention in atrial fibrillation: a crosssectional study. BMJ Open 3:e003343. https://doi.org/10.1136/ bmjopen-2013-003343

61. Andrade JG, Verma A, Mitchell LB et al (2018) 2018 Focused update of the Canadian Cardiovascular Society Guidelines for the Management of atrial fibrillation. Can J Cardiol 34:1371-1392. https://doi.org/10.1016/j.cjca.2018.08.026

62. Dowling TC, Wang E-S, Ferrucci L, Sorkin JD (2013) Glomerular filtration rate equations overestimate creatinine clearance in older individuals enrolled in the baltimore longitudinal study on aging: impact on renal drug dosing. Pharmacother J Hum Pharmacol Drug Ther 33:912-921. https://doi.org/10.1002/phar.1282

63. Steffel J, Verhamme P, Potpara TS et al (2018) ESC Scientific Document Group. The 2018 European Heart Rhythm Association Practical Guide on the use of non-vitamin K antagonist oral anticoagulants in patients with atrial fibrillation. Eur Heart $\mathbf{J}$ 39:1330-1393

64. January CT, Wann LS, Calkins H et al (2019) 2019 AHA/ACC/ HRS Focused Update of the 2014 AHA/ACC/HRS Guideline for the Management of Patients With Atrial Fibrillation: a report of the American College of Cardiology/American Heart Association Task Force on Clinical Practice Guidelines and the Heart Rhythm Society. J Am Coll Cardiol 9(74):104-132. https://doi. org/10.1016/j.jacc.2019.01.011

65. Makani A, Saba S, Jain SK et al (2020) Safety and efficacy of direct oral anticoagulants versus warfarin in patients with chronic kidney disease and atrial fibrillation. Am J Cardiol 125:210-214

Publisher's Note Springer Nature remains neutral with regard to jurisdictional claims in published maps and institutional affiliations. 